\title{
CPD FOR MEMBERS OF AUDITING PROFESSION IN INDONESIA: PROVIDERS' POINT OF VIEW
}

\author{
Ayu Chairina Laksmi \\ Accounting Department, Faculty of Economics, Universitas Islam Indonesia \\ e-mail: rien1977@yahoo.com
}

\begin{abstract}
In accounting, CPD is a relatively new area of research and therefore worthy of attention. CPD for public accountants and CPA (Certified Public Accountant) holders in Indonesia are compulsory, however, studies into the compulsory CPD is still limited. Using semi-structured interview as its data collection method and thematic analysis as its data analysis tools, this study investigates CPD for the members of auditing profession through CPD providers' - which is the Indonesian Institute of Certified Public Accountants or IICPA and the Indonesian Institute of Accountants or IIA - point of view. Through purposive sampling employed in this study, three people from the IICPA and one person from IIA are interviewed in 2011 and 2012. The people interviewed are the staff who plan, organise and monitor CPD offerings directly. The findings of this study demonstrate that the IICPA is the main provider of CPD for the members of auditing profession, however, their compliance to IFAC requirements on CPD is still questionable. The IIA is also another CPD provider, although the number of auditing profession members who join their CPD declines every year. The roles of IICPA in offering CPD are to educate through improving knowledge and professionalism and to ensure public accountants' compliance towards rules and regulations. Both IICPA and IIA do not appear to have a framework in offering their CPD. Furthermore, they also do not organise CPD based on the needs of individual CPD participants from different level in the organisation. Finally, the findings also show that unlike the IIA that do not focus their CPD based on specific needs, the IICPA focuses their CPD offerings on both individual and organisational needs.
\end{abstract}

Key words: CPD, Continuing Professional Development, auditing profession, Indonesia

\begin{abstract}
Abstrak
Di bidang akuntansi PPL merupakan area penelitian yang relatif masih baru dan oleh karenanya layak untuk mendapatkan perhatian. PPL untuk akuntan publik dan pemegang sertifikat CPA (Certified Public Accountant) di Indonesia wajib dilaksanakan, akan tetapi studi yang meneliti PPL wajib ini masih terbatas. Dengan menggunakan interview semi terstruktur sebagai metode pengumpulan data dan analisis tematik sebagai alat pengolah data, studi ini menginvestigasi PPL untuk anggota profesi auditing di Indonesia melalui sudut pandang penyedia PPL yaitu Ikatan Akuntan Publik Indonesia (IAPI) dan Ikatan Akuntan Indonesia (IAI). Melalui purposive sampling studi ini mewawancarai tiga orang dari IAPI dan satu orang dari IAI. Semua partisipan yang diwawancarai di studi ini adalah para staf yang secara langsung merencanakan, mengatur dan memonitor aktivitas PPL yang ditawarkan kepada anggota profesi auditing di Indonesia. Hasil studi ini menunjukkan bahwa IAPI adalah penyedia PPL yang utama. Akan tetapi kepatuhan IAPI terhadap peraturan dari IFAC mengenai PPL masih dipertanyakan. IAI juga menyelenggarakan PPL meski jumlah anggota profesi auditing yang mengambil PPL dari IAI terus menurun setiap tahunnya. Peran IAPI dalam kaitannya dengan PPL adalah mengedukasi dengan cara meningkatkan pengetahuan dan profesionalisme dan juga untuk memastikan kepatuhan akuntan publik terhadap peraturan dan perundangan yang ada. Baik IAPI maupun IAI tidak mempunyai suatu kerangka dalam menawarkan PPL mereka. Selain itu, IAPI dan IAI tidak menyelenggarakan PPL berdasarkan kebutuhan yang berbeda dari individu partisipan PPL berdasarkan tingkatnya di dalam organisasi. Hasil studi ini juga menunjukkan bahwa tidak seperti IAI yang tidak memfokuskan PPL mereka terhadap suatu kebutuhan khusus, IAPI memfokuskan PPL mereka baik untuk kebutuhan pribadi maupun kebutuhan organisasi.
\end{abstract}

Kata Kunci: PPL, Pendidikan Profesional Berkelanjutan, profesi audit, Indonesia 


\section{INTRODUCTION}

Continuing Professional Development or CPD is an important activity and also a condition of membership in many professions, including accounting. Professional accountants have a responsibility to the public, and to professional accountants themselves, to ensure that they continue to develop and maintain the competence demanded by their professional roles and by the clients who use their services (Paisey, Paisey and Tarbert 2007). Furthermore, professional accountants must ensure that they keep up to date with any matters related to their profession (Guthrie 2004; Paisey, Paisey and Tarbert 2007; Rothwell and Herbert 2007; Ciccotosto, Nandan and Smorfitt 2008; IFAC 2008; De Lange, Jackling and Suwardy 2010; De Lange et al. 2012; Lindsay 2012; Udin et al. 2012). Keeping up to date has become paramount for professional accountants since accounting knowledge continues to develop and change rapidly (Berg 2007).

In the accounting context, CPD is a relatively new research area. According to Paisey and Paisey (2004) although professional issues in the accounting profession have been discussed extensively, CPD is still an under-researched area and is therefore worthy of attention. This study investigates CPD for the auditing profession in Indonesia, in particular CPD for public accountants and CPA holders. At the moment, the members of auditing profession in Indonesia gather in these two accounting professional bodies: 1) Indonesian Institute of Accountants (the IIA) and; 2) Indonesian Institute of Certified Public Accountants (the IICPA).

Currently, public accountant is the only accounting profession in Indonesia that is required to undertake $C P D$ by the law. The Public Accountant Act (the Act Number 5 of 2011) affirms that the public accountants must undertake CPD. There are also other auditors who are CPA holders but have not yet registered as public accountant. The IICPA in its bylaw (IICPA 2012) states that CPD is a continuous learning that is compulsory for its members in order to maintain, improve and develop their professional competencies. Si- milarly, the IIA (2012) also states that CPD is compulsory for all of its members and CPD for the members follows IFAC's rule. It can be concluded that both public accountants and CPA holders who are members of the IICPA and the IIA must undertake CPD according to the law and professional bodies' regulation.

The overall aim of this study is to investigate how and why CPD for the public accountants and CPA holders in Indonesia is conducted from the providers' point of view. This study focuses on the IICPA and the IIA as the CPD providers for the members of auditing profession in Indonesia. The study uses qualitative methodology since this study aims to find out how and why the CPD providers organise their CPD. Small sample size is acceptable in qualitative methodology since generalisability is not the issue (McCracken 1988; Shank 2002; Bryman and Bell 2006). Data is collected through semi-structured interview and thematic analysis is used as a data analysis tools in analysing themes that surface from the interview. Thematic analysis is one common data analysis in qualitative research and it has demonstrated its usefulness in investigating CPD for the professional accountants.

Three people from the IICPA and one person from the IIA are interviewed in this study. These people are the key staff who plan and organise CPD offerings for the members of auditing profession. The representatives from the IICPA are: (1) the Chief Professional Education Officer who is responsible for organising CPD activities for the auditing profession in Indonesia; (2) the Chief Education Implementation Agency, the agency is responsible for overseeing and monitoring the organisation of CPD by the Professional Education Officer; and (3) a member of the Education Implementation Agency. The representative from the IIA is the Director of Education and Certification whose duty is to oversee all matters related to education, including CPD, and also members' professional certification. To protect the identity of the participants of this study, they are identified simply as Interviewee 1 , Interviewee 2, Interviewee 3 and Interviewee 4 as shown in Table 1 below. 
Table 1: The IICPA Representatives' Profile

\begin{tabular}{ccl}
\hline No. & Identifier & \multicolumn{1}{c}{ Position } \\
\hline 1 & Interviewee 1 & Chief Professional Education Officer - IICPA \\
2 & Interviewee 2 & Member of Education Implementation Agency - IICPA \\
3 & Interviewee 3 & Chief Education Implementation Agency - IICPA \\
4 & Interviewee 4 & Director of Education and Certification - IIA \\
\hline
\end{tabular}

The next section discusses a literature review of CPD and followed by discussion on research methodology used in this study. The findings of this study are presented in results and discussion section. Conclusion provides recommendations, limitations, future research directions, and final remarks.

\section{LITERATURE REVIEW}

This section provides a review of the literature on CPD. The review discusses choice of CPD provider, compliance to IFAC requirements on CPD, role of professional body, CPD framework, different CPD for different level in the organisation, organisation's role in offering $\mathrm{CPD}$, and focus of CPD offering.

\section{Choice of CPD Provider}

Currently there are two professional bodies for accountants in Indonesia. These bodies are the Institute of Certified Public Accountants (IICPA) and the Indonesian Institute of Accountants (IIA). Public accountants and CPA holders in Indonesia must become members IICPA. Furthermore, they can also be a member of IIA and register with various governmental institutions such as the Central Bank, the Capital Market and Financial Institution Supervisory Agency and the State Audit Board. Despite the various professional and government bodies, which bodies that are allowed to organise CPD for the public accountants and CPD holders in Indonesia is still unclear. Therefore, it is useful to investigate whether all or some of the aforementioned professional and regulatory bodies are also CPD providers.

\section{Compliance to IFAC Requirements on CPD}

The International Education Standards (IES) 7 published by IFAC in 2004 and then redrafted in 2012 contains the requirement of CPD for
IFAC members. The IES 7 (IFAC 2004) suggests the IFAC member bodies to promote to their members, stakeholders and the public, the benefits of CPD highlighting the importance of continuous improvement of competence and a commitment to lifelong learning and to facilitate access to CPD opportunities and resources to assist professional accountants in meeting their responsibility for lifelong learning. The IIA is a member body of IFAC The IICPA is the member body of the IIA (IIA 2012) and, hence, the IICPA must conform to the IFAC requirements in offering CPD to the members of auditing profession in Indonesian.

Currently, there is limited literature or information available regarding how the CPD offerings by the CPD providers conform to the IFAC requirements. Therefore, it is helpful to find out whether or not the CPD offering for the members of auditing profession in Indonesia conform to the IES 7 from the CPD providers' point of view.

\section{Role of Professional Body}

Professional bodies are definers, controllers, supporters and also suppliers of CPD activities (Dix 1995; Friedman and Phillips 2004; Friedman 2012). Many of these activities have been part of the normal working of a professional body long before CPD is formalised. Moreover, in recent years there has been a proliferation of CPD policy-making by professional bodies (Rapkins 1996). These policies are the means by which professional bodies have responded to the changes faced by members in technology and knowledge, the demand for quality assurance and accountability from the public, and the need to increase the competitiveness of the economy.

Most professionals are always kept up to date with developments and changes in their 
field of practice. Nonetheless, CPD has been conceived as basic activities and ad hoc, and it is aimed more to respond immediate specific needs and updating rather than a continuing development process (Jones and Robinson 1997; Friedman 2012). Although it is recognised that such an urgent need for professional development will always need to be met, the changing demands faced by the profession needs a more planned approach to CPD (Rapkins 1996). As a result, professional bodies have put themselves at the forefront of the development of this approach through CPD.

Furthermore, Rapkins (1996) also argues that in building a favourable environment for $\mathrm{CPD}$, there must be a recognition and development partnership between all those who will benefit from and have the responsibility for CPD. Those parties are individual professionals, professional bodies, employers, providers, and communities. The professional bodies as the initiator - and often the provider of CPD, play an important role. The need for continuous learning should be instilled during initial professional education to establish a synthesis of initial and continuing education. Thus, professionals must get support and guidance on CPD and it is one of the tasks of professional bodies

Up to now, it is still unclear who is responsible in offering, planning and monitoring CPD for the public accountants and CPA holders in Indonesia. As previously mentioned, there are two accounting professional bodies in Indonesia. Therefore, it will be advantageous to find out the role of accountant professional bodies in Indonesia in offering CPD.

\section{CPD Framework}

A CPD framework is considered useful for professional associations in offering CPD for their members. Some well-known nonaccounting professional bodies have developed CPD frameworks to support their CPD offerings. The Association of University Administrators UK (2009), for example, maintains that their CPD framework provides the basis for a common national approach to CPD for professional staffs, provides institutions with a broad structure within which to identify the CPD needs of professional staffs in their organisations and to plan and deliver development activities to meet those needs. From medical practitioner professional body, the Royal Australian and New Zealand College of Obstetricians and Gynaecologists (2011) provides a CPD framework as part of their Learning, Education and Professionalism project and they believe that it offers flexibility, breadth, and rigour needed to facilitate relevant and effective CPD for today's medical specialists.

According to Allinson (2010), CPD framework helps the professionals to consider their current and future desired practice roles. A CPD framework is beneficial in the sense that it covered the whole aspect of CPD. Thus, the framework provided a structured and fundamental platform for the development of professional competency of individual professionals and sustainability the profession as a whole. Furthermore, Allinson (2010) also argues that CPD is also implemented to the mutual benefits of the individual professional, employers, the profession, and society as a whole. Consequently, a framework can facilitate in bringing together the various stakeholders' point of views regarding CPD and what CPD should be doing in fulfilling the professionals' needs. Given the importance of a CPD framework, it is useful to investigate the framework used by CPD providers for the Indonesian public accountants and CPA holders in offering their CPD.

\section{Different CPD for Different Level in the Organisation}

CPD participants' different level in the organisation does matter in CPD. Wood and Anderson (2003) find that those who are in the 3-5 years on the profession are more open to CPD opportunities than more established professionals whom they perceive as less so. Studies by Hustler et al. (2003) and Sim and Radloff (2009) demonstrate that more recently qualified professionals have more positive dispositions towards CPD. A more complex reason may be that the more recent generation of pro- 
fessionals has a higher regard for education. It can also be argued that the more senior professionals are afraid of change due to feeling less well prepared than their younger counterparts (Sim and Radloff 2009). Hustler et al. (2003) also argue that there is a practice of segmentation, which is an activity of identifying distinct groupings in the workforce, for example by age, gender, experience or responsibility and planning their needs in relation to their expected beliefs, attitudes and dispositions towards their professional life.

Pool, Poell and Cate (2013) find that younger and older professionals perceive CPD differently since CPD purpose and the contributing learning activities are considered to change during the lifespan. They argue that the requirements and needs of different age group of professionals should be considered when developing strategies for CPD. Learning from the abovementioned studies, it will be more beneficial if CPD is designed to meet different needs of different segments or levels in the organisations. Therefore identifying common characteristics in segments of the workforce may lead to CPD that is tailored to the different segments.

It is arguably a difficult task to meet all individual needs in terms of CPD. Nevertheless, it is the duty of professional bodies to try to meet their members' individual needs. Professional bodies should have a clear CPD policy that defines CPD, the aims of CPD and how they will achieve those aims. Rapkins (1996) maintains that it is best when professional bodies provide a structured and systematic CPD throughout a professional career. From accounting profession, De Lange, Jackling and Suwardy (2010) find that one-size fits all approach to CPD is inappropriate and that professional bodies should aim CPD at different level in the organization. In another words, CPD for the professionals - including accountants - should be differentiated according to their career stages of level in the organisation. Therefore, it is important to find out whether or not CPD for the Indonesian public accountants and CPA holders is already customised to different level of organisation.

\section{Focus of CPD Offerings}

Knowles, Holton and Swanson (2005) maintain that exploring the gaps between research and practice is a primary role for the professionals. The call to action is to implement best known practices and to assess valid learning needs, create and implement valid strategies for achieving learning goals and conduct valid assessment of learning and that effort should be directed at organisation needs as well as those of individual professionals. Sim and Radloff (2009) argue that professionals need to focus their CPD on both personal level and on workplace level. They elaborate further that CPD helps individual professionals to reflect on their current practice. The reflective practitioners take ownership of their learning and are driven by motivation to learn in order to advance their practice in their workplace. As a result, organisational needs of having competent staff can be fulfilled by CPD indirectly. Learning needs of individual professional and organisational needs, hence, should be both taken into account. This study will try to seek the CPD providers' opinion regarding the focus of CPD they offer to the members of auditing profession. Should CPD be focused on individual personal development only, or should the organizations' needs be taken into account as well when determining CPD.

\section{RESEARCH METHODOLOGY}

This study employs a qualitative methodology since the aim of this study is to find out how and why CPD for the members of auditing profession in Indonesia is conducted from the CPD providers' point of view. Hennink, Hutter and Bailey (2011) explains that qualitative methodology are typically used for providing an indepth understanding of the research issues that involves the perspectives of the study population and the context in which they live. In particular qualitative research is also useful for exploring new topics or understanding complex issues; for explaining people's belief and behavior, and for identifying the social or cultural norms of a culture or society (Hennink, Hutter and Bailey 2011). Therefore, qualitative me- 
thodology is suitable for this study since research CPD in the accounting context is considered as new area and worthy of attention.

The data collection method chosen is semi-structured interview since this method allowed the participants to have authority over their own stories, which means that they are seen as "experts". This is important since CPD for accounting profession in Indonesia is a rarely investigated area, thus, lots of information needed to be gathered to answer the research question of this study. Moreover, semistructured interviews offer a more flexible approach to interview process than structured interviews (Bryman and Bell 2006; Ryan Coughlan and Cronin 2009) and interviews enable the words and perspective of the participants to emerge (Hesse-Biber and Leavy 2010). The semi structured interviews in this study are conducted with four participants from accounting professional bodies in Indonesia in 2011 and 2012.

Coding is conducted in this study prior to data analysis. The coding of the data follows the guideline set out by Saldana (2013) and Miles, Huberman and Saldana (2014). The First Cycle coding and the Second Cycle coding are employed in order to find the perfect fit for the data of this study. Both of the cycles coding are very helpful in identifying various themes emerged in this study. Thematic analysis is employed in this study as a data analysis tools. A theme captures something important about the data in relation to the proposed research questions, and represents some level of patterned response or meaning within the data set (Braun and Clarke 2006). Three stages of thematic analysis are conducted in this study and the stages follow Boyatzis (1998), Braun and Clarke (2006), Howitt and Cramer (2008), and Jones and Forshaw (2012). The first stage is transcribing textual material. This process is based on the qualitative data collection method employed in this study, which is the semi-structured interview. Reading and transcribing the data increased this investigator's familiarity with the materials. In other words, the transcription process was part of the process of analysis. The whole process from interview to translation of interview texts assisted this investigator to become familiar with the text early and this continued throughout the data analysis. The second stage of the analysis is conducting analytic effort. This refers to the amount of work or processing that this investigator applies to the text in order to generate the final themes, which are the endpoint of thematic analysis (Braun and Clarke 2006; Howitt and Cramer 2008). The analytic efforts conducted in this study are: (a) this investigator becomes increasingly familiar with the text via semi-structured interviews, and transcribing and translating the interview texts, so that understanding can be achieved, thereby avoiding partial knowledge of the data; (b) this investigator works to obtain the details of the data, both by analysing each sentences and entire passages from the study participants' answers, in order to summarise the overall themes; (c) this investigator processes and reprocesses the data in order to achieve as close a fit of the analysis to the data as possible; (d) this investigator checks and rechecks the fitness of the data analysis process. The third and last stage is identifying themes and sub-themes. According to Braun and Clarke (2006), researchers differ considerably in terms of how and how carefully they choose to refine the themes, which emerge from their analysis. Therefore, this investigator works carefully to decide on appropriate coding for the data and on the useful and employable themes that emerged from those data. This investigator continues with this process until the work is deemed to be has gone as far as possible. This process of continuing with analysis in qualitative methodology until one can go no further is known as 'saturation' (Hennink, Hutter and Bailey 2011; Jones and Forshaw 2012; Richards and Morse 2013).

For validity, this study follows the guidelines provided by Kvale and Brinkmann (2009). This study relies on the quality of the interview process for the validity of the materials and interviewing a number of participants in order to be able to verify one another's answers. Preparation before interview such as carefully drafted interview questions, the use 
of a good quality audio recording, interview guide, and also allocating a minimum of one hour for each interview help this investigator to conduct good quality interviews. Building a rapport with the participants during the interviews is also crucial in this study. This investigator also tries to gather as many stories as possible from the participants in order to understand and to make meaning of their experiences and understanding regarding CPD. Moreover, this study also follows the interview guide to ensure that the interviews run smoothly and in the right direction. After all, 'the best guarantee of the validity of interview material is careful, concrete level, interviewing within the context of a good interviewing partnership' (Weiss 1994, p. 150).

\section{RESULTS AND DISCUSSION}

From the CPD providers' point of view, Interviewee $1,2,3$, and 4 unanimously state that the IICPA is the only CPD provider for the public accountants and CPA holders in Indonesia and it is appointed directly by the Indonesian Government through the Law no 5 of 2011. Interviewee 4 explains as follows regarding CPD providers for the members of auditing profession:

"Definitely the IICPA (is the CPD provider) for the public accountants. But there are also other institutions that are recognised by the IICPA. One of those institutions is the IIA. Recognised means not all of (CPD) credit points (from other providers) are fully recognised."

Thus, the findings demonstrate that the IIA is not the main CPD provider for the auditing profession in Indonesia. The IIA provides CPD but credit points from that CPD will not be fully recognised by the IICPA. When asked whether or not other organisations also providing CPD for the public accountants in Indonesia, Interviewee 1 replies:

"I don't know whether or not the other organisations provide CPD. But the IICPA should be the one to organise CPD for the public accountants. I think the Law No. 5 of 2011 already appointed the IICPA to organise CPD. But the Ministry of Finance also has an interest in CPD, which is why they give the (CPD) topics to us. Usually, their topics are related to government's regulations. So they only give us the topics or the speakers, but we organise it (CPD)."

Meanwhile, Interviewee 2 states that the IICPA is the only CPD provider for public accountants in Indonesia. Interviewee 2 also explains that although the IICPA is the only provider, it also gives a leeway for the public accountants to undertake CPD from other providers, for example from the IIA or other organisations. However, the IICPA only recognises 15 per cent of the total credit points. The reason for the restriction is CPD quality from other organisations cannot be monitored by the IICPA:

"Because, we can't monitor the quality of CPD (for the public accountants) if other organisations organise it. If the IICPA organises CPD, we monitor it through the presence sheet. Every (CPD) participant must sign the presence sheet, if the CPD is a one day seminar; they have to sign twice, in the morning and in the lunch time."

Similar answer regarding CPD held by other providers apart from the IICPA is received from Interviewee 3:

"Well, what we want is this: we want to guard the (CPD) content, we must avoid it (CPD content) to get out of control. We need to make the content strict in order to maintain accounting practices (in Indonesia) in accordance with the competence development program launched by the IICPA. For example, this year we want to shift our focus to International Auditing Standard (IAS) preparation. So this year we're preparing for IAS, last year we were preparing for IFRS. (But) other providers only did whatever they like 
to do. So that's the goal of this program (CPD). Besides we have a (control) mechanism through presence sheet. We want to make sure that the (CPD) participants were there so the eight credit points (given to them) are really controlled, not only fictitious."

The findings on choice of CPD providers demonstrate that the Indonesian government appoints the IICPA as the main CPD provider for the public accountants. The IICPA also has the authority to assess CPD undertaken by the public accountants from other providers. Nonetheless, the IICPA only recognises 15 per cent of CPD credit points for CPD undertaken from organisations other than the IICPA due to quality control issue. Moreover, for other members of the auditing profession such as the CPA holders, there are no current regulations regarding their CPD providers. Thus, it can be assumed that they can undertake CPD from any providers.

The CPD providers are also asked whether or not the current CPD offerings meet the IFAC requirements of CPD as stated in the IES 7. For this question, Interviewee 3 does not want to answer because he is not ready to answer the question. When he is asked further regarding the IFAC requirement of 120 credit points in three-year period, he answers that the current regulation requires the public accountants to undertake 30 credit points per year, hence, in 3 years period it will be accumulated to 90 credit points. He also emphasises that the IICPA calculates the CPD credit points per year, not every three-year period. The reason for that is as follows:

"...so they (the public accountants) will be more disciplined, that is based on my own experience in organising CPD. Now we have CPD all year long. At first we only had CPD towards the end of the year and they (public accountants) must achieve the (CPD) target in three-year period. Just imagine if a person procrastinates and does all the credit points towards the end of the third year, that's not good. So I think for us (the IICPA), we have to be strict".

The findings also demonstrate that Interviewee 2 does not really know the content of the IES 7. Nonetheless, Interviewee 2 acknowledges that the IICPA must adhere to the IES 7 since the IICPA is a member body of the IIA and the IIA is a member body of IFAC. The IICPA already put in their best efforts to follow the IES 7 for example by organising CPD for the members, set the minimum credit points requirements and provides updated topics. When asked further regarding the requirements of 120 credit hours of CPD in three-year period, Interviewee 2 explains that the majority of the public accountants are doing more than 30 credit points of CPD per year. One CPD seminar has 8 credit points and normally people do more than 4 days of CPD per year, hence, the 30 credit points will be achieved automatically. Similarly, Interviewee 1 does not read the IES 7 content, however, Interviewee 1 assures that the IICPA already follows the IFAC requirements on CPD credit points. For the quality of $\mathrm{CPD}$, however, Interviewee 1 is not so sure whether or not they have follow IFAC's requirements. Representing the IIA, Interviewee 4 explains that CPD that they organise has followed IFAC requirements:

"Sure, we follow (IFAC requirements), the (CPD) structure follows them. But nowadays we hardly get public accountants as participants of our CPD. So, now we mainly serve non-public accountants and the public. But our (CPD) structure, minutes calculation, who the instructurs are, we follow IFAC (requirements)."

Furthermore, Interviewee 4 provides answer below when asked whether or not the IICPA which is a member body if the IIA at the time of interview - follows IFAC requirements:

"I didn't get that information (CPD organised by the IICPA). If I'm not mistaken, the IICPA refers to the Ministry of Finance regulations. For their CPD, they (the IICPA) refer to their internal 
requirements. I don't know whether or not they have followed the IES 7. The IICPA should comply but they have their independence, autonomy. Therefore, we can't give them any sanctions if they don't follow the IES 7."

The abovementioned answers demonstrated that the IIA representative understands IFAC requirements on CPD and implements them. Conversely, the representatives from the IICPA are not sure whether or not they have followed the IFAC requirements in providing CPD for their members. This finding is quite interesting since the CPD providers for the members of auditing profession should adhere to global and national regulations of CPD that are applied to them. The IIA should monitor the IICPA's CPD because the IICPA is a member body of the IIA. Since the IIA is a member body of IFAC, the IICPA needs to adhere to IFAC regulations apart from adhering to the Indonesian government's regulation on CPD.

Professional bodies undoubtedly play an important role in organising and offering CPD for the members and this has supported by the literature (Dix 1995; Rapkins 1996; Friedman and Phillips 2004; Friedman 2012). When asked regarding the IICPA role regarding CPD, Interviewee 1 explains as follows:

"Yes, we are the profession's organisation; one of our roles is to organise education of this profession, in the form of CPD. So our role is to improve the horizon, knowledge, and professionalism of this profession... Knowledge in auditing, knowledge as an accountant."

Quite different from Interviewee 1, Interviewee 2 put emphasis on public accountants' compliance to the rules and regulations:

"We have one role which is to ensure the public accountants follow the rules. If they don't undertake CPD, we will be warned by the Ministry of Finance. Furthermore, we need to ensure they receive the latest information regarding development in accounting, auditing, industry, regulations, and so on. By updatig their knowledge, they aut omatically will maintain their competence."

Interviewee 3's answer is similar to Interviewee 1 in terms of the IICPA role in organising $\mathrm{CPD}$ for the public accountants. Interviewee 3 states the IICPA does all of the procedures in organising CPD from planning to execution. The IICPA needs to maintain the quality and continuity of CPD because it is the place where the public accountants can meet and interact with each other. Thus, it can be concluded that the IICPA roles in offering CPD are to educate the members of auditing profesion through improving knowledge and professionalism and to ensure public accountants' compliance towards rules and regulation from the government bodies. Interviewee 4 from the IIA mentions as follows regarding their role in offering CPD:

"The IIA's role is to continue organising CPD. Before the IICPA received its independence as an organisation in, the public accountants undertake their CPD from the IIA. But since 2010, the number went down drastically to near zero. It went down especially since the new Law no. 5 of 2011 was enacted. The IIA's CPD credit points can be recognised (by the IICPA) but only a few per cent of credit point. That's the IICPA's internal rule. The IIA has no authority since the new Law states that the IICPA is the public accountants' regulator. The IICPA is a member body of the IIA but for CPD, well you know how it is. There's a collaboration between the IICPA and other organisations, especially in regions like Surabaya, Palembang, Medan, etc. As far as I know, the IICPA asks for an income-sharing, 70 per cent of the income is for them. So we never... we never consider a collaboration with the IICPA in organising CPD due to that big income-sharing. " 
From the above discussion, it can be concluded that the IICPA is indeed plays an important role as a CPD provider for the public accountants in Indonesia. They have a strong position and are supported by the Law. This finding regarding the IICPA as a definer, controller, and also suppliers of CPD activities supports previous literature by Dix (1995), Friedman and Phillips (2004) and Friedman (2012). However, there is also a concern about monopoly of CPD by not recognising fully CPD credit points from other providers. Furthermore, there is also a question regarding CPD for CPA holders, who are also members of the auditing profession. It appears that the Indonesian government and the IICPA put more emphasis on CPD for the public accountants rather than the CPA holders.

As previously mentioned, a CPD framework is beneficial in underpinning CPD offering for the professionals (Allinson 2006). The findings of this study demonstrate that CPD providers do not have a particular framework in organising and offering CPD for the members of auditing profession in Indonesia. Interviewee 1 explains that the IICPA uses the need of auditors as the basis for its CPD offerings. Furthermore, Interviewee 1 explains that the IICPA focuses on giving a variety of topic such as financial accounting, auditing, management accounting, taxation and soft skills such as leadership, IT, report writing, or, human resource management etc. Regarding CPD framework, Interviewee 2 explains that every year the IICPA must submit a catalogue of CPD to the Ministry of Finance. So the catalogue will provide topics of CPD for one year ahead. The catalogue is based on development and updates of the current standards and regulations. The CPD participants' feedbacks are also taken into account into catalogue development by the IICPA. The IICPA also asks for feedbacks and input from the people in the Accounting Standards Council and also the Auditing Standards Council for the interesting and current topics. The Accounting Standards Council is the council that set the accounting standards in Indonesia and is under the IIA. The Auditing Standards
Council is under the IICPA and its role is to set the auditing standards for the public accounting profession in Indonesia. Interviewee 3 explains that the IICPA does not have any framework in organising CPD. Instead, the IICPA put emphasis on the focus of CPD. The IICPA focuses on giving face-to-face and interactive CPD to the CPD participants. They also focus on restricting CPD undertaken from other providers apart from the IICPA in order to ensure the right direction of CPD. The variety of accounting firm sizes in Indonesia also poses another problem. The Big Four firms may have more internal training facilities, when compared to smaller accounting firms. As a result, the IICPA works hard to ensure that CPD does not discriminate towards the accounting firm sizes. Furthermore, the IICPA focuses more on core accounting topics such as financial standards, auditing, stock market, and banking. Interviewee 3 also admits that soft skills are indeed important, however, there is a limited space and time to allocate. The IICPA also tries to accommodate the nonpublic accountants participants - such as the CPA holders - by organising special CPD with no credit points but offer cheaper registration fees. The topics are usually technical knowledge topics such as audit working papers. Although the special CPD offer a cheaper registration fee, the CPD offerings will be of high quality according to the CPD standards set by the IICPA. Interviewee 4 explains that the IIA uses the Indonesian Financial Accounting Standards as the framework that underpins their CPD offerings.

To sum up, the findings on CPD framework reveals that the IICPA as the sole provider of CPD for the members of auditng profession currently does not have a framework to underpin the current offerings. Instead of a framework, the IICPA uses the need of the auditors, the development and updates of the current standards and regulation as the basis in organising CPD for the auditors. Similarly, the IIA also does not have a certain framework for its CPD and only uses the Indonesian Financial Accounting standards as guidance. Therefore, this finding does not 
support Allinson (2006) and also different from other professional bodies that have a framework to underpin their CPD offerings. It can be concluded based on the above findings that CPD for the auditing profession in Indonesia is still at ad-hoc level without a thorough planning and organisation.

The CPD providers are asked whether or not the current CPD offerings cater for different level of organisations. Interviewee 1 explains that the IICPA does not differentiate between CPD for public accountants or nonpublic accountants. However, the IICPA sometimes organises special CPD only for the non-public accountants such as the CPA holders. According to Interviewee 1, the special CPD will help the smaller accounting firms with limited resources in providing trainings for the staff. Similarly, Interviewee 2 comments that the IICPA only differentiate CPD for public accountants and non-public accountants:

"The differences between CPD for public accountants and non-public accountants are: CPD for non-public accountants is more detailed, workshop type, tends to discuss real practice such as journal and paperwork making; and the price is cheaper since we're assuming lots of people will be interested."

Interviewee 3 states that the current CPD offerings are mainly aimed at the public accountants. Furthermore, accounting firms normally send their public accountants staff to attend CPD events and sometimes non-public accountant staff too when the CPD topics are interesting or important to them. Similar to other interviewees, Interviewee 4 explains as follows:

"We don't... differentiate. We don't classify our CPD based on the participants' level in their organisations. What we see is the (CPD) topics. For example, we have the latest financial accounting standards, so in three days (of CPD) we provide a lot of topics on that standards. This means we focus more on introduction to theory. But when the topic is about gap analysis, that's more focused. Usually, the participants will be like 'okay', so if they don't understand the standards they will not join the gap analysis. Yes, gap analysis is for the more experienced ones. So we decide our topics not based on their needs but we prefer to provide a lot of menus (CPD topics) that they can choose based on their needs. There's no disappointment (from attending the wrong CPD topics), but even if there is, they won't protest to us. Our outlets already explain (to the participants) what the topics will be about."

The above findings demonstrate that the CPD providers for the members of auditing profession in Indonesia do not differentiate CPD for different level of organisation. This finding does not support previous research by Rapkins (1996); Wood and Anderson (2003); Hustler et al. (2003); De Lange, Jackling and Suwardy (2010) and Pool, Poell and Cate (2013). In particular, De Lange, Jackling and Suwardy (2010) points out that professional bodies should differentiate CPD based on the level of organisations since each career stage has different needs. Nonetheless, it appears that the IICPA already provides some form of differentiated CPD for the non-public accountants but still without taking into account their career stage.

CPD offerings must have a focus since individual needs may differ from organisations' needs. This study investigates the focus of CPD offered by the CPD providers, individual needs or organisation needs or both. Interviewee 1 explains as follows:

"The committee (at the IICPA), are from accounting firms. Therefore, accounting firms' needs can be represented by them. I'm a partner (at an accounting firm) myself. So at least we know what we need. We also have a gathering, we call it FORKAP (Forum Komunikasi Akuntan Publik/Public Accountants Communication Forum), 
it's an accounting firms forum, and it's also a kind of gathering forum for the accounting firms. The IICPA only focuses on its individual members, but we also have this forum and we work together (in that forum). We even have outing programs when we're bored with classrooms (activities). We've tried outbound activities. We're planning to do it again this November."

Meanwhile, Interviewee 2 explains that the IICPA determined the needs of accounting firms from the feedback forms distributed to all of the CPD participants at the end of CPD events.

"Usually we get accounting firms' needs from feedback forms. Because what we do is... we have CPD for partners (public accountants) only, with CPD credit points. But we also have CPD for staff with no CPD credit points. CPD for the staff are more detailed. Let's just say CPD for partners, it (CPD) only gives outlines. On the contrary, CPD for staff are more of a workshop, with a longer duration and also a cheaper price."

Interviewee 3 explains that the IICPA just piloted a number of partnerships with one of the Big Four firms to hold an in-house CPD event and the event is open for everyone to attend. Furthermore, according to Interviewee 3, the IICPA intends to design a curriculum together with accounting firms and help smaller accounting firms that do not have their own training facilities. Interviewee 4 maintains that at the IIA does not include accounting firms' needs in focusing their CPD offerings:

"We don't usually communicate with the accounting firms (to find what they need). But accounting firms' staff come to us. Yes, the ones who don't need CPD credit points. They (accounting firms) send them to us. CPD for latest financial standards, syariah accounting, they come to us. But the public accountants don't come (to our CPD). Even Big Four send (their staff) to us."
The findings on focus of CPD offerings demonstrate that the IICPA focuses on both individual and organisational needs and this confirm previous study by Knowles, Holton and Swanson (2005) and Sim and Radloff (2009). The IICPA is also quite proactive in collaborating with accounting firms and seek feedback from them regarding their needs of CPD. Individual needs also a focus for the IICPA and the feedback from CPD participants are useful in determining CPD topics. On the contrary, the IIA appears to be not having a specific focus on their CPD offerings. Regardless, their CPD is somewhat popular with the non-public accountants members of the auditing profession and this is maybe due to the fact that IIA offers plenty of popular topics to choose from.

\section{CONCLUSION}

Several major findings emerge from the interviews conducted with three representatives from the IICPA and one representative from the IIA. For the choice of CPD provider, it is found that the IICPA is the main provider of CPD for the auditing profession. The IICPA also has the authority to recognise CPD undertaken with other CPD providers, such as the IIA. The findings also demonstrate that the representatives from the IICPA are not sure whether or not they have followed IFAC requirements in providing CPD. Conversely; the IIA appears to be more aware that their CPD must adhere to IES 7 published by IFAC in 2004. In terms of role of professional body, the findings demonstrate that the IICPA roles in offering CPD are to educate the members of auditng profession through improving knowledge and professionalism and to ensure public accountants' compliance towards rules and regulation from the government bodies. Similarly, the IIA's role is also as a CPD provider although the number of public accountants who undertake CPD with the IIA dwindles every year. Concerning CPD framework to underpin CPD offerings, both the IICPA and the IIA maintain that they do not have a specific framework. Current updates on governmental rules and regulations; and also on ac- 
counting standards have helped the CPD providers on planning and organising CPD offerings. The CPD providers' answers also demonstrate that both the IICPA and the IIA do not cater for different level of organisations in offering CPD. However, the IICPA put some efforts in providing special CPD for nonpublic accountants participants. Hence, some forms of differentiated CPD for the members of auditing profession do exist and these certainly beneficial considering non-public accountants' needs - including CPA holders must also be accommodated. Furthermore, the IICPA seems to focus their CPD offerings on both individual and organisational needs. In contrast to the IICPA, the IIA do not focus on particular needs for their CPD. However, the IIA states that they offer a broad variety of CPD topics to choose from.

Based on the findings of this study, the following recommendations can be made: 1) It will be beneficial for the members of auditing profession in Indonesia to have more options regarding recognised CPD providers; 2) CPD providers should be aware of and comply to IFAC requirements on $\mathrm{CPD}$; 3) $\mathrm{A} \mathrm{CPD}$ framework can be established by the professional bodies to support CPD offerings. A framework will help to focus CPD offerings in order to meet individual and organisational needs of the members of auditing profession; 4) The professional bodies as CPD providers and the Indonesian government should also take into accounts non-public accountants members of the profession, especially the CPA holders. CPD for the CPA holders should also be made compulsory and be monitored. This is to ensure that the members of the auditing profession in Indonesia are all maintaining and updating their competence continuously. Furthermore, the CPA holders are only steps away from becoming public accountants, thus, their existence and their needs are equally important and should be accommodated; 5) CPD should cater for different level of of organisations or career stage, hence, the professional bodies as CPD providers should be able to capture different needs of CPD and satisfy those needs; 6) CPD provid- ers should focus on both individual and organisational needs. In order to meet those needs, CPD providers should be proactive in seeking feedback from individual participants and also from accounting firms - be it Big Four or small firms - in Indonesia.

This study limits its scope to investigate CPD for the members of auditing profession in Indonesia from CPD providers' point of view. Another limitation of this study is it does not investigate CPD for other accounting profession in Indonesia, such as tax accountants, management accountants, public sector accountants, accounting educators, etc. The nature of qualitative methodology employed in this study also possesses some inherent limitations since reality is seen as multiple, subjective; and also cannot be generalised to the population. Future reserch on this particular topic can also include CPD participants, using quantitative methods or combination of qualitative and quantitative methods; and also involve other accounting professions in order to acquire a broader view of CPD.

\section{REFERENCES}

Allinson, Y. 2010. Demystifying the new CPD. The Australian Journal of Pharmacy 91: 34.

Association of University Administrator. 2009, Continuous Professional Development framework for staff working in professional services in higher education,

$<$ http://www.aua.ac.uk/professional_de velop-

ment/cpd/framework_doc/documents/c pd_framework.pdf $>$ (accessed 30 July 2011).

Berg, M. C. 2007. Continuing Professional Development - The IFAC position, Accounting Education 16 (4): 319-27.

Boyatzis, R. E. 1998. Transforming qualitative information: Thematic analysis and code development. Thousand Oaks: Sage Publication, Inc. 
Braun, V., and V. Clarke. 2006. Using thematic analysis in psychology. Qualitative Research in Psychology 3 (2): 77-101.

Bryman, A., and E. Bell. 2006. Business research methods. Oxford: Oxford University Press.

Ciccotosto, S., R. Nandan, and D.B. Smorfitt. 2008. Issues facing small accounting practices in regional North Queensland: An exploratory study. Australian Accounting Review 18 (4): 324-333.

De Lange, P., B. Jackling, and T. Suwardy. 2010. Access to CPD opportunities and resources to assist professional accountants to meet their commitment to lifelong learning: Evidence from the Asia Pacific region. IAAER. http://files.iaaer.org/research/de_Lange Final_Report.pdf?1406817147 (accessed 7 September 2011).

De Lange, P., B. Jackling, I.G. Basioudis, A. Halabi, S. Ravenscroft, and T. Suwardy. 2012. A framework of best practice of Continuing Professional Development for the accounting profession. IAAER.

http://files.iaaer.org/research/Delange and Jackling_et_al_Final_Report_Dec 10_2012.pdf?1406817950 (accessed 9 March 2013).

Dix, C. 1995. Continuing professional development: Challenge and change. In Continuing professional development: Perspectives on CPD in practice, ed. S. Clyne. London: Kogan Page Limited.

Friedman, A. L., and M. Phillips. 2004. Continuing professional development: developing a vision. Journal of Education and Work 17 (3): 361-376.

Friedman, A. L. 2012. Continuing professional development: Lifelong learning of millions. Abingdon: Taylor \& Francis.

Guthrie, L. 2004. Action reply. Financial Management November: 26-27.
Hennink, M., I. Hutter, and A. Bailey. 2011. Qualitative research methods. London: SAGE Publications.

Hesse-Biber, S. N., and P. Leavy. 2010. The Practice of qualitative research. London: SAGE Publications.

Howitt, D., and D. Cramer. 2008. Introduction to research methods in psychology. Prentice Hall.

Hustler, D., O. McNamara, J. Jarvis, M. Londra, A. Campbell, and J. Howson. 2003. Teachers' perspectives of Continuing Professional Development: DfES Research Report No. 429. London: DfES.

IFAC. 2004. International Education Standard IES $7 . \quad$ IFAC $<$ http://web.ifac.org/publications/intern ational-accounting-educationstandards-board/handbook\#handbookof-international-e> (accessed $22 \mathrm{Au}-$ gust 2011).

. 2008. Approaches to Continuing Professional Development (CPD) measurement. IFAC. http://www.ifac.org/sites/default/files/p ublications/files/approaches-tocontinuing-pr.pdf (accessed 30 August 2011).

IIA. 2012. CPD Profile. $<$ http://www.iaiglobal.or.id/v02/ppl/pp 1.php?id=6> (accessed 1 September 2012).

IICPA. 2012. Directory 2012. 27 January 2012 ed. IICPA. Jakarta: 1 August 2012.

Jones, N. and G. Robinson. 1997. Do organizations manage continuing professional development? Journal of Management Development 16 (3): 197-207.

Jones, S., and M. Forshaw. 2012. Research methods in psychology. Harlow: Pearson Prentice Hall.

Knowles, M. S., E.F. Holton III, and R.A. Swanson. 2005. The adult learner: The Definitive classic in adult education 
and human resource development. San Diego: Elsevier, Inc.

Kvale, S., and S. Brinkmann. 2009. Interviews: Learning the craft of qualitative research interviewing. Thousand Oaks: SAGE Publications, Inc.

Lindsay, H. 2012. Pattern of learning in the accountancy profession under an outputbased continuing professional development scheme. Accounting Education: An International Journal 21 (6): 615-630.

McCracken, G. 1988. The Long interview. Newbury Park: Sage Publications, Inc.

Miles, M. B., A.M. Huberman, and J. Saldaña. 2014. Qualitative data analysis: A Methods sourcebook. 3rd ed. Thousand Oak: SAG Publications, Inc .

Paisey, C., and N.J. Paisey. 2004. An analysis of accounting education research in Accounting Education: an international journal - 1992-2001. Accounting Education: an International Journal 13 (1): 69-99.

Paisey, C., N.J. Paisey, and H. Tarbert. 2007. Continuing professional development activities of UK accountants in public practice. Accounting Education 16 (4): 379-403.

Pool, I., R. Poell, and O. T. Cate. 2013. Nurses' and managers' perceptions of continuing professional development for older and younger nurses: A Focus group study. International Journal of Nursing Studies 50 (1): 34-43.

Royal Australian and New Zealand College of Obstetricians and Gynaecologists. 2011. Continuing Professional Development for medical practitioners. http://www.ranzcog.edu.au/leapframe work/history research.shtml. (accessed 1 August 2011).

Rapkins, C. 1996. Best practice for Continuing professional development: Professional bodies facing the challenge, in Continuing Professional Development:
Issues in Design and Delivery. ed. I Woodward. London: Cassell.

Richards, L., and J. M. Morse. 2013. Readme first for a user's guide to qualitative methods, 3rd ed. Thousand Oaks: SAGE Publications, Inc.

Rothwell, A. and I. Herbert. 2007. Accounting professionals and CPD: Attitudes and engagement-some survey evidence. Research in Post-Compulsory Education 12 (1): 121-138.

Ryan, F., M. Coughlan, and P. Cronin. 2009. Interviewing in qualitative research: the one-to-one interview. International Journal of Therapy and Rehabilitation 16 (6): 309-314.

Saldaña, J. 2013. The coding manual for qualitative researchers 2 nd ed. Thousand Oaks: SAGE Publications.

Shank, G. D. 2002. Qualitative research: A Personal skills approach. Upper Saddle River: Pearson Education Inc.

Sim, J. and A. Radloff. 2009. Profession and professionalisation in medical radiation science as an emergent profession. Radiography 15 (3): 203-208.

Udin, N. M., N. A. A. Manaf, Z. Ishak, and R. AR. 2012. KnowledgeManagement I nternational Conference (KMICe), 4-6 July, 2012: Tax professionals' views on Continuing Professional Development (CPD) programs. Johor Baru: Malaysia.

http://www.kmice.cms.net.my/ProcK MICe/KMICe2012/PDF/CR178.pdf (accessed 2 March 2014).

Weiss, R. S. 1994. Learning from strangers: The Art and method of qualitative interview studies. New York: Free Press.

Wood, D. E., and J. Anderson. 2003. Towards the learning profession: Identifying characteristics of successful Continuing Professional Development in schools. Management in Education 17 (21): 21-24. 